\title{
Sphingolipids and mitochondrial function, lessons learned from yeast
}

\author{
Pieter Spincemaille ${ }^{1}$, Bruno P.A. Cammue ${ }^{1,2, *}$ and Karin Thevissen ${ }^{1}$ \\ ${ }^{1}$ Centre of Microbial and Plant Genetics (CMPG), KU Leuven, Kasteelpark Arenberg 20, 3001 Heverlee, Belgium. \\ 2 Department of Plant Systems Biology, VIB, Technologiepark 927, 9052, Ghent, Belgium. \\ * Corresponding Author: Bruno P.A. Cammue, Centre for Microbial and Plant Genetics, KU Leuven, Kasteelpark Arenberg 20; 3001 \\ Heverlee, Belgium; Tel: +32 16329682; Fax: +32 16321966; E-mail: bruno.cammue@biw.kuleuven.be
}

\begin{abstract}
Mitochondrial dysfunction is a hallmark of several neurodegenerative diseases such as Alzheimer's disease and Parkinson's disease, but also of cancer, diabetes and rare diseases such as Wilson's disease (WD) and Niemann Pick type C1 (NPC). Mitochondrial dysfunction underlying human pathologies has often been associated with an aberrant cellular sphingolipid metabolism. Sphingolipids (SLS) are important membrane constituents that also act as signaling molecules. The yeast Saccharomyces cerevisiae has been pivotal in unraveling mammalian SL metabolism, mainly due to the high degree of conservation of SL metabolic pathways. In this review we will first provide a brief overview of the major differences in SL metabolism between yeast and mammalian cells and the use of SL biosynthetic inhibitors to elucidate the contribution of specific parts of the SL metabolic pathway in response to for instance stress. Next, we will discuss recent findings in yeast SL research concerning a crucial signaling role for SLs in orchestrating mitochondrial function, and translate these findings to relevant disease settings such as WD and NPC. In summary, recent research shows that $S$. cerevisiae is an invaluable model to investigate SLS as signaling molecules in modulating mitochondrial function, but can also be used as a tool to further enhance our current knowledge on SLs and mitochondria in mammalian cells.
\end{abstract}

\author{
doi: $10.15698 / \operatorname{mic} 2014.07 .156$ \\ Received originally: 18.04.2014; \\ in revised form: 02.06.2014, \\ Accepted 10.06.2014 \\ Published 25.06.2014.
}

Keywords: yeast, sphingolipids, mitochondrial function, Wilson disease, Niemann Pick type C1.

\section{INTRODUCTION}

Aberrancies in mitochondrial function generally termed mitochondrial dysfunction are characteristic of a plethora of human pathologies such as cancer [1, 2], Parkinson's disease [3], Alzheimer's disease [4], Friedreich's ataxia [5], Wilson's disease (WD) [6], metabolic syndrome and nonalcoholic fatty liver disease [7-10], diabetes [11] and druginduced liver injury [12, 13]. Mitochondrial dysfunction originates from (i) inherited mutations in genes encoding subunits of the electron transport chain (ETC) located on both nuclear and mitochondrial DNA (mtDNA) [14, 15], (ii) acquired mutations that arise during the normal aging process but also as a result of chronic hypoxia, viral infections, radiation, chronic stress or chemical pollution [16-25] and (iii) drug treatments such as antivirals and chemotherapeutics $[12,13]$. Interestingly, several mitochondrial dysfunction-related conditions are associated with a perturbed sphingolipid (SL) metabolism [26-34]. SLS are important components of cell membranes [35] and play a crucial role as signaling molecules orchestrating cell growth, differentiation and apoptosis [36-38].

The yeast $S$. cerevisiae (baker's or budding yeast) has been broadly exploited as a eukaryote model organism since the publication of its genome in 1996, resulting in the annotation of approximately 6000 genes located on 16 chromosomes [39]. Sequencing of the mtDNA was performed independently in 1998 [40]. In contrast, the human mtDNA sequence was already published in 1981 [41] and in 1988 the first mtDNA mutation-related human pathology was identified as Leber's hereditary optic neuropathy (LHON) [42]. LHON is characterized by optic nerve degeneration that leads to visual impairment or blindness [43]. Interestingly, approximately $31 \%$ of the protein-coding genes in yeast have a mammalian orthologue [44] and $30 \%$ of the genes known to be involved in human diseases may have a yeast orthologue $[45,46]$. Remarkably, pathways that modulate apoptosis and mitochondrial function, as well as SL metabolism, are well conserved from yeast to 
higher eukaryotes [47-52]. These aspects make yeast an extremely useful tool to study human diseases.

Given the numerous reports connecting SLs, mitochondrial (dys)function and human pathologies, and the position of $S$. cerevisiae as a model organism, we here provide an overview of literature on the interplay between SLS and mitochondrial (dys)function in the yeast $S$. cerevisiae and will translate these findings to relevant diseases characterized by mitochondrial dysfunction and/or aberrant SL metabolism. When we discuss yeast in this review, it typically refers to $S$. cerevisiae.

\section{MITOCHONDRIA, CELLULAR POWERHOUSES}

Mitochondria are double-membraned dynamic cell organelles that constantly change shape through fusion and fission $[53,54]$ and are present in the cytoplasm of all eukaryotic cells, except mature erythrocytes [23]. The mitochondrial membranes consist of a mixture of lipids with the most abundant species phosphatidylcholine (PC), phosphatidylethanolamine (PE) and to a lesser extent cardiolipin $(\mathrm{CL})$ in mammalian cells, whilst in yeast the most abundant species are $P C$ and $P E$, and to a lesser extent $C L$ and phosphatidylinositol (PI) [55]. The primordial function of mitochondria is ATP production via oxidative phosphorylation (OXPHOS). However, mitochondria also play a crucial role in the regulation of cell processes such as apoptosis and cellular ion homeostasis. For more detailed descriptions on mitochondrial function and structure, the reader is referred to [56, 57].

In mammalian cells, cellular energy is mainly produced via aerobic respiration, although energy can also be generated via glycolysis in absence of oxygen, which is however far less efficient [58]. In contrast, tumor cells display high rates of glycolysis in the presence of sufficient oxygen, also known as the Warburg effect [59, 60]. Interestingly, by using specific carbon sources, yeast metabolism can either be shifted towards high glycolysis, combined glycolysis and respiration, or respiration alone by forcing growth on glucose, galactose or glycerol, respectively [61,62], which is advantageous to investigate the role of respiration in a specific cellular process.

\section{SPHINGOLIPIDS}

In general, SLs are classified as lipids that contain a sphingoid base as the structural backbone, further decorated by a polar head group and a fatty acid side chain. Three major classes of sphingoid backbones are known: sphingosine (Sph), dihydrosphingosine or sphinganine (dhSph) and phytosphingosine (phytoSph) [63]. Next to their function as membrane constituents, SLs act as important signaling molecules. Traditionally, the central SL ceramide (Cer), Cer1-phosphate (Cer-1-P), Sph and Sph-1-phosphate (Sph-1-P) are well characterized bioactive SLs with roles in cell growth, apoptosis, inflammation, proliferation, and others [64-66]. Intriguingly, SLs have been linked to mitochondrial function in both mammalian cells and yeast [67-74].

Several tools have contributed to our understanding of $\mathrm{SL}$ metabolism, signaling and composition in mammalian and yeast cells. For instance, mass spectrometry methods are commonly used to detect different SL species and quantify their abundance in response to various stimuli [75, 76]. In addition, inhibitors of SL metabolism are routinely used to elucidate the role of SLs in various settings [77-86]. Despite the high degree of conservation of SL metabolic pathways between mammalian and yeast cells [52, 87, 88], there are still yeast- and mammalian-specific aspects, and particularly in biosynthetic pathways. The major yeast and mammalian SL metabolic pathways are outlined in Fig. 1.

In the following part we subsequently describe both the mammalian and yeast SL metabolism, and discuss the use of SL biosynthetic inhibitors.

\section{Mammalian sphingolipid metabolism}

In mammalian cells, the central SL Cer can be generated via either de novo biosynthesis or the salvage pathway [89] (Fig. 1). De novo Cer biosynthesis typically starts with the condensation of serine and palmitoyl CoA to 3ketodihydrosphingosine by the serine palmitoyltransferase enzyme (SPT) [90]. 3-Ketodihydrosphingosine is subsequently reduced to $\mathrm{dhSph}$ by 3-ketodihydrosphingosine reductase [91]. Addition of a fatty acid side chain via an amide bond to dhSph then yields dihydroceramide (dhCer), which gets desaturated to Cer by Cer synthase [92] and dihydroceramide desaturase (dhCer desaturase) respectively [93]. dhSph can also be generated from ceramidase (CDase)-mediated catabolism of dhCer [94]. Cer is converted to Sph by CDase [94] or Cer-1-P by the action of Cer kinase [95]. In addition, Cer serves as precursor for the formation of complex SLs such as sphingomyelin (SM) by SM synthase [96] or glucosylCer/galactosylCer by addition of phosphocholine or a carbohydrate, respectively, as polar headgroup. Glucose is incorporated by glucosylCer synthase to yield glucosylCer [97], whereas galactose is incorporated by Cer galactosyl transferase to generate galactosylCer[98, 99]. SM interacts with cholesterol in the plasma membrane forming SM-cholesterol-rich domains and regulates cholesterol distribution in cellular membranes and cholesterol homeostasis in cells [100]. GlycoSLs can function as receptor for carbohydrate binding proteins on the membrane to initiate transmembrane signaling events as well as cell growth, differentiation and cell-to-cell communication [101-104]. GlucosylCer and galactosylCer can either be catabolized to Cer by glucocerebrosidase [105] or galactosylceramidase [106], respectively, or serve as precursor in the formation of more complex glycoSLs. Cer also serves as precursor in the formation of low levels phytoceramide (phytoCer) by the action of dhCer desaturase $[107,108]$. Sphingomyelinases (SMases) break down SM to Cer [109]. Sph and dhSph are phosphorylated by Sph kinases to produce Sph-1-P and dhSph-1-phosphate (dhSph1-P), respectively [110]. Cleavage of Sph-1-P and dhSph-1-P into phosphoethanolamine and hexadecenal, catalyzed by Sph-1-P lyase [111-113], represents the only exit route from the SL pathway. In turn, Sph1-P and dhSph-1-P are dephosphorylated by Sph-1-P phosphatase to yield Sph and dhSph, respectively [112, 114], while Cer-1-P is dephosphorylated by Cer-1-P phosphatase generating Cer 
[115]. The salvage pathway to generate Cer refers to the catabolism of complex SLs into Cer and then Sph by CDasemediated Cer breakdown. These Sph species can be reacylated by Cer synthase to Cer [89].

\section{Yeast sphingolipid metabolism}

De novo SL production is conserved from yeasts to mammals up to the synthesis of dhSph (Fig. 1) [52]. In yeast, dhSph is hydroxylated to phytoSph by sphinganine $\mathrm{C}_{4}$ hydroxylase (Sur2p) [116]. The sphingoid bases dhSph and phytosphingosine (phytoSph) are commonly referred to as long chain bases (LCBs) in yeast. Next, a fatty acid side chain is added to phytoSph or dhSph, both catalyzed by the yeast Cer synthase, i.e. Lag1p and Lac1p [117], generating phytoCer and dhCer, respectively. The former is the central $\mathrm{SL}$ in yeast. Sur2p-mediated hydroxylation of dhCer then generates phytoCer [116]. In addition, the yeast dihydroceramidase (Ydc1p) and yeast phytoceramidase (Ypc1p) hydrolyze dhCer to dhSph [118] and phytoCer to phytoSph [119], respectively. Polar headgroups can be added to phytoCer in order to generate different species of complex SL. In yeast, three major complex SL species exist: (i) inositolphosphoceramide (IPC) is created by extending phytoCer with phospho-inositol by IPC synthase (Aur1p and Kei1p) [120], (ii) addition of mannose to IPC by mannose inositolphosphoceramide (MIPC) synthase (Csg1p , Csg2p and Csh1p) generates MIPC [121], and (iii) addition of another phospho-inositol residue to MIPC, catalyzed by inositol phosphotransferase (Ipt1), leads to the generation of mannose diinositolphosphoceramide $\left(\mathrm{M}(\mathrm{IP})_{2} \mathrm{C}\right)$ [122]. Breakdown of the three complex SLs in yeast is catalyzed by inositol phosphosphingolipid phospholipase C (Isc1p) to generate phytoCer and dhCer $[123,124]$. Next to their role as precursor in the formation of phytoCer, the LCBs dhSph and phytoSph can be phosphorylated by LCB kinases (Lcb4p and Lcb5p) to generate dhSph-1-P and phytoSph-1$P$, respectively [125]. The phosphorylated LCBs can then either be dephosphorylated back to dhSph and phytoSph by LCB-1-phosphate (LCB-1-P) phosphatases (Lcb3p and Ysr3p) [126-128], or catabolized by dhSph phosphate lyase (Dpl1) yielding phosphoethanolamine and hexadecenal [129]. For a more detailed description the reader is referred to [130].

\section{Sphingolipid biosynthetic inhibitors}

To date, the best characterized and most used inhibitors of $\mathrm{SL}$ biosynthesis in yeast research include Myriocin (Myr), isolated from Myriococcum albomyces and Mycelia sterilia [131]; Aureobadisin A (Aur A), isolated from Aureobasidium pullulans [132]; and Fumonisin B1 (FB1), isolated from Fusarium monoliforme [133]. Myr inhibits de novo SL biosynthesis in all eukaryotes by binding the first biosynthetic enzyme SPT [90, 134-136], while Aur A inhibits yeast IPC synthase [137]. FB1 inhibits Cer synthase in yeast and

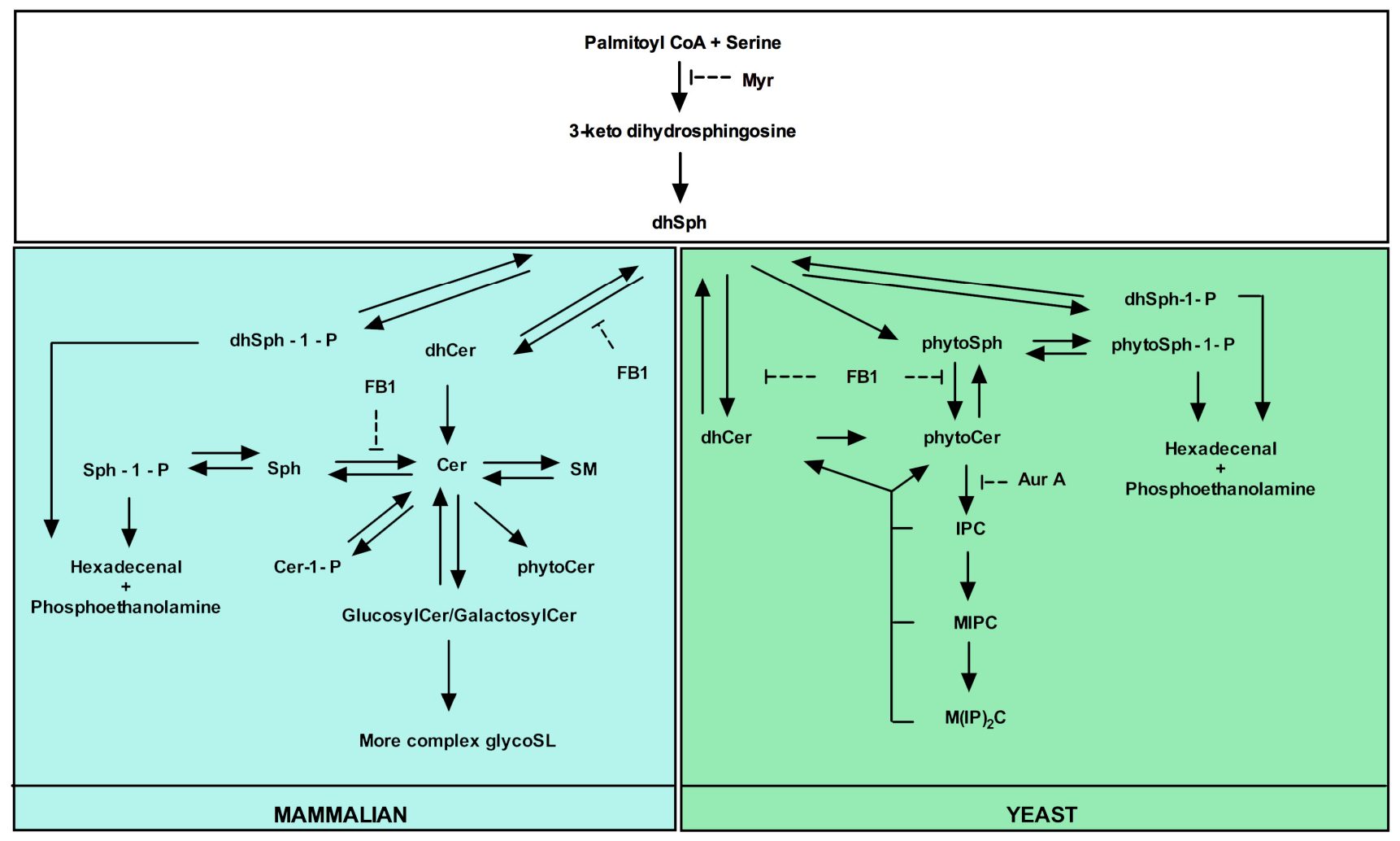

FIGURE 1: Major yeast and mammalian SL metabolic pathways. Both overlapping parts (white square) and yeast- (green square) and mammalian (blue square)-specific processes are indicated as well as the targets of commonly used inhibitors of SL biosynthesis. Adapted from [87]. 
mammalian cells (Fig. 1) [138, 139].

Inhibitors of specific SL biosynthetic enzymes are broadly exploited to synthetically affect different parts of the SL metabolic pathway in order to elucidate the origin of SLs in specific settings. A well-studied case has been the unraveling of the role of de novo SL biosynthesis during heat stress in yeast. Heat stress induces a transient cell cycle arrest in yeast [140] followed by resumption of growth at the elevated temperature [141] and several studies have implicated SLs in the heat stress response. For instance, heat stress causes a transient 2-3-fold increase of $\mathrm{C}_{18}$-dhSph and $\mathrm{C}_{18}$-phytoSph levels, an over 100 -fold transient increase in $\mathrm{C}_{20}$-dhSph and $\mathrm{C}_{20}$-phytoSph, a stable 2-fold increase in $\mathrm{C}_{18}$-phytoSph containing $\mathrm{Cer}$ and a 5-fold increase in $\mathrm{C}_{20}$-phytoSph containing Cer [142]. Dickson and coworkers observed accumulation of the disaccharide trehalose, which is essential for protection against heat stress [143]. This effect is related to the LCB-induced expression of the trehalose biosynthetic gene TPS2 [144]. In addition, blocking synthesis of complex SLs by Aur A treatment, leading to an accumulation of LCBs and Cer, induces TPS2 expression at non-stressing temperatures. Furthermore, Aur A potentiates the effect of dhSph or heat stress on TPS2 expression [142]. Similar findings regarding heat stressinduced accumulation of LCBs and Cer were reported by Jenkins and coworkers but also that complex SLS are unaffected while Cer levels are increased, which was partially abrogated by FB1 treatment [145]. Taken together, these findings indicate a role for de novo SL synthesis during heat stress.

Several additional studies indicated that specific SL species fulfill different roles in the regulation of particular cellular responses. For instance, Jenkins and Hannun reported that LCBs are likely to be the active species to trigger cell cycle arrest during heat stress, which was confirmed as exogenous addition of either dhSph or phytoSph induces transient cell cycle arrest [146]. In addition, during heat stress de novo SL biosynthesis is responsible for LCBS and phytoCer production, while Isc1p-mediated hydrolysis of complex SLs accounts for dhCer production [147]. In addition, $\Delta i s c 1$ mutants display a similar cell cycle arrest as compared to the wild type strain during heat stress, indicating that Isc1p-mediated SL generation does not affect cell cycle regulation during heat stress [147]. Montefusco and coworkers addressed the specific role of distinct Cer species in SL signaling in yeast via a lipidomic and transcriptomic analysis of yeast cultures treated with different combinations of heat stress, Myr and the fatty acid myristate $\left(C_{14}\right)$ [148]. Their results indicate that long chain dhCer species $\left(C_{14}\right.$ and $\left.C_{16}\right)$ affect the expression of genes related to iron ion transportation while very long chain dhCer species $\left(C_{18}, C_{18: 1}, C_{20}\right.$ and $\left.C_{20: 1}\right)$ are involved in the vacuolar protein catabolic process.

A role for stress-related SL signaling is not limited to heat stress in yeast, but has also been implicated in stress induced by toxic iron. Iron toxicity is directly related to the generation of deleterious reactive oxygen species (ROS) [149]. Lee and coworkers linked SLs to iron toxicity as high iron increases the levels of LCBs and LCB-1-Ps, and decreas- ing these levels by Myr treatment increases yeast tolerance to high iron [150]. These data point to a signaling role for LCBs and LCB-1-Ps in iron toxicity. In yeast, LCBs are known to directly phosphorylate protein kinases such as Pkh1p, which is redundant with Pkh2p and related to mammalian 3-phosphoinositide-dependent protein kinase PDK1 [151], and Ypk1p and its paralogue Ypk2p, related to serum- and glucocorticoid-inducible kinase (SGK) [151, 152]. Alternatively, $\mathrm{Ypk} 1 / 2 \mathrm{p}$ is phosphorylated by Pkh1p in response to LCBs. Regarding a signaling role for LCBs during iron toxicity, loss of either Pkh1p or Ypk1p indeed increases yeast tolerance to high iron [150]. Hence, LCB-based SL signaling is involved in the cellular response during iron toxicity. For additional information concerning heat and iron stress in yeast and signaling pathways mediated by LCBs the reader is referred to $[150,153-156]$. Taken together, these findings suggest that SLs fulfil a crucial signaling role during various stress conditions and that specific SL species orchestrate differential responses.

\section{CLUES FROM YEAST RESEARCH THAT LINK SLS TO MI- TOCHONDRIAL FUNCTION}

The use of SL biosynthetic inhibitors in the lower eukaryotic model yeast, $S$. cerevisiae, has provided interesting insights into the interplay between SLs and mitochondrial function. For instance, Myr does not induce killing in yeast cells lacking mitochondrial DNA [157], i.e. $\rho^{0}$ cells, suggesting that decreased de novo SL synthesis is detrimental for cell viability and requires functional mitochondria. In addition, in yeast lifespan regulation is linked to SLS as Myr treatment extends yeast chronological lifespan (CLS), which is associated with decreased levels of LCBs, LCB-1-Ps and IPCs [78]. The yeast protein kinase Sch9p is a known regulator of longevity in yeast [158] and is activated upon phosphorylation by LCBs directly or via LCB-induced activation of Pkh1/2p [151]. In addition, Sch9p is phosphorylated by the action of the Target of Rapamycin Complex 1 (TORC1) [159], involved in nutrient signaling [159]. The reduction in SL levels upon Myr treatment during CLS was proposed to decrease activity of the Pkh1/2p-Sch9p signaling axis resulting in an increased CLS. However, a Sch9pindependent effect on CLS was also described as Myr treatment increases CLS of $\Delta$ sch9 mutants [78]. Subsequently, the effect of Myr on CLS was shown to be related to its effect on the yeast transcriptome. Myr treatment during yeast ageing results in the upregulation of many genes linked to mitochondrial function and oxidative phosphorylation but also to stress responses and autophagy, and downregulation of genes related to ribosomes, cytoplasmic and mitochondrial translation, as well as to ER glycoprotein and lipid biosynthesis [160]. Hence targeting SL biosynthesis has provided insights in a link between SLs and regulating mitochondrial function.

Next to $S$. cerevisiae, the use of higher eukaryotic model organisms such as Caenorhabditis elegans has also significantly contributed to our current understanding of mammalian SL metabolism, and has pointed to a connection between SLS and mitochondrial function. Mitochondrial 
defects in C. elegans are detected by a surveillance pathway, which causes the induction of mitochondrial chaperone genes such as $h s p-6$, but also drug-detoxification genes such as cyp-14A3 and ugt-61 [161-164]. As such, a RNA interference (RNAi) screen in C. elegans was conducted, thereby aiming at identifying genes that, upon their inactivation, renders nematodes unable to activate the mitochondrial surveillance pathway in response to mitochondrial dysfunction induced by drugs or by genetic interruption. Among their hits was sptl-1, encoding the $C$. elegans SPT. For instance, Sptl-1 inactivation renders nematodes unable to upregulate $h s p-6$ in response to inhibition of the mitochondrial electron transport by Antimycin, while no effect on hsp-6 is observed in absence of Antimycin [164]. In addition, knockout of both Cer synthase genes decreases hsp-6 induction upon mitochondrial damage while Myr prevents Antimycin-induced $h s p-6 p$ expression. Strikingly, exogenous addition of $\mathrm{C}_{24^{-}} \mathrm{Cer}$, but not dhCer or $\mathrm{C}_{16^{-}}, \mathrm{C}_{20^{-}}$or $\mathrm{C}_{22}$-Cer, restores the ability of sptl-1(RNAi) animals to trigger $h s p-6$ expression in presence of Antimycin, but not in absence of Antimycin [164]. Hence, this indicates that SLs are involved in the cellular response to mitochondrial dysfunction and that distinct SLs do serve an important signaling role in modulating mitochondrial function in higher eukaryotes in general.

In mammalian cells, the specific underlying mechanisms that connect SLs, and more specifically Cer to mitochondrial function mainly remain unclear. Nevertheless, Cer species are present in mitochondria and there are various reports that link Cer species to mitochondrial function as (i) Cer species are required for ETC complex activity, but can also inhibit ETC complexes and induce the formation of reactive oxygen species (ROS), (ii) Cer species reduces the $\Delta \psi_{m}$ by mitochondrial pore formation, triggers mitochondrial outer membrane permeabilization and thus initiates apoptosis, and (iii) Cer species are determinants for the induction of mitophagy [67]. Mitophagy is a mitochondrial quality control mechanism that eliminates dysfunctional and aged mitochondria [165]. Next to these aspects (i-iii) that were recently reviewed [67], other reports that link Cer species to mitochondrial function in mammalian cells include (iv) the presence of Cer-producing enzymes in the mitochondria. El Bawab and coworkers described the identification of a human CDase that localizes to the mitochondria and is ubiquitously expressed, with the highest expression levels in the kidneys, skeletal muscles and heart [166]. Also, purified mitochondria and the mitochondriaassociated membrane from rat liver synthesize Cer in vitro via Cer synthase or reverse CDase activity [167] and there are studies describing the identification of a novel SMase that displays mitochondrial localization in zebrafish and mice as discussed below [168, 169]. Lastly, in addition to the above-mentioned links between Cer and mitochondrial function (i-iv) there are (v) reports that link Cer species to mitochondrial fission events. Mitochondrial fusion is a compensatory mechanism to decrease stress by mixing the contents of partially damaged mitochondria, while mitochondrial fission is referred to as mitochondrial division in order to create new mitochondria. Both mitochondrial fusion and fission are closely involved in cell processes such as mitophagy, cell death and respiration [170]. As described by Parra and coworkers, in contrast to $\mathrm{C}_{2}$-dhCer, $\mathrm{C}_{2}$ Cer induces rapid fragmentation of the mitochondrial network in rat cardiomyocytes and increased mitochondrial content of the mitochondrial fission effectors Drp1 and Fis1 [171, 172]. Additionally, inhibition of Cer synthase decreases recruitment of Drp1 and Fis1 to the mitochondria and concomitantly also reduces mitochondrial fission [173]. Moreover, Smith and coworkers showed that $C_{2}$-Cer addition causes rapid and dramatic division of skeletal muscle mitochondria, which is characterized by increased Drp1 expression and reduced mitochondrial respiration. Interestingly, these effects are abrogated by Drp1 inhibition [174]. These reports directly link Cer species to mitochondrial fission. Taken together, there is abundant evidence that links SLs to mitochondrial function in mammalian cells.

In the following part we will first describe novel findings with regard to the SL-mitochondria connection using yeast as a model and translation of these findings to relevant higher eukaryotic settings related to mitochondrial (dys)function. We will hereby focus on Isc1p and Ncr1p, the yeast orthologue of the Niemann Pick type C1 (NPC) disease protein [175]. Also, in the context of WD, a pathological condition characterized by excess $\mathrm{Cu}$ and mitochondrial dysfunction [176], we will describe the potential of yeast as a model to identify novel compounds that can inhibit $\mathrm{Cu}$-induced apoptosis in yeast.

\section{Inositol phosphosphingolipid phospholipase C (Isc1p) and} mitochondrial function in S. cerevisiae

In $S$. cerevisiae, several reports have linked SLs to mitochondrial function via the action of Isc1p [68-73]. Reportedly, Isc1p mainly resides in the ER, but localizes to the outer mitochondrial membrane during the late exponential and post-diauxic growth phase $[68,71,177,178]$. Isc1p is homologous to the mammalian neutral SMases (nSMase) [124]. Interestingly, a novel SMase in zebrafish cells was identified that localizes to the intermembrane space and/or the inner mitochondrial membrane [168]. Furthermore, a novel murine nSMase was reported to localize to both mitochondria and ER termed mitochondria-associated nSMase (MA-nSMase) [169]. MA-nSMase expression varies among tissues and like Isc1p in yeast $[123,179]$ its activity is highly influenced by phosphatidylserine and CL [169]. Though a human MA-nSMase has not yet been characterized, a putative human MA-nSMase encoding gene has been identified [180]. It is therefore conceivable that the MA-nSMase is the mammalian counterpart of yeast Isc1p, though this has yet to be elucidated as well as a putative role for human MA-nSMase in regulating mitochondrial function by modulating SL-levels.

Isc1p and its associated SL species have been extensively studied as regulators of mitochondrial function as several studies demonstrated that $\Delta i s c 1$ mutants display several markers of mitochondrial dysfunction such as a decreased CLS [70], the inability to grow on a non-fermentable carbon source $[69,71,72,181,182]$, increased frequency of petite 
formation [178], mitochondrial fragmentation [72] and abnormal mitochondrial morphology [73]. Furthermore, $\Delta i s c 1$ mutants display an aberrant cellular and mitochondrial SL composition as $\Delta i s c 1$ mutants exhibit decreased levels of all SLs with the most striking decreases in $\alpha-\mathrm{OH}$ $\mathrm{C}_{24}$-phytoCer and $\alpha-\mathrm{OH}-\mathrm{C}_{26}$-phytoCer species, while $\alpha-\mathrm{OH}$ $\mathrm{C}_{14}$-phytoCer and $\mathrm{C}_{26}$-phytoCer levels are increased [178]. In addition, $\Delta i s c 1$ mutants are characterized by decreased dhSph and $\alpha$-OH-phytoCer levels and increased $\mathrm{C}_{26}$-dhCer and $\mathrm{C}_{26}$-phytoCer levels during CLS [181]. Strikingly, exogenous addition of $\mathrm{C}_{12}$-phytoCer allows $\Delta i s c 1$ mutants to grow on a non-fermentable carbon source [71]. In line with Cowart and coworkers who reported that $\Delta i s c 1$ mutants display aberrant gene regulation [147], Kitagaki and coworkers revealed that mitochondrial dysfunction related to loss of Isc1p is caused by a misregulation of gene expression rather than an inherent mitochondrial defect as $\Delta i s c 1$ mutants are unable to up-regulate genes that are involved in non-fermentable carbon source utilization, and down-regulate genes related to nutrient uptake and amino acid metabolism [182]. This points to an important signaling role for Isc1p-mediated SL generation in regulating mitochondrial function in yeast.

Currently identified downstream signaling proteins related to perturbed mitochondrial function in $\Delta i s c 1$ mutants include the type 2A-related serine-threonine phosphatase Sit4p [183], the mitogen-activated protein kinase Hog1p, involved in response to hyperosmotic stress [184-187], and the TORC1/Sch9p pathway $[69,72,177,181]$. The TORC1/Sch9p signaling pathway however is proposed as the central signaling axis to pass upstream SL signals to downstream effectors such as Hog1p and Sit $4 p$ that affect mitochondrial function [72]. It is likely that additional signaling pathways are also involved in modulating mitochondrial function in response to SLs, however, these pathways have yet to be identified. For more information concerning our current knowledge on how SLs related to the action of Isc1p are implicated in regulating mitochondrial function, and the role of the aforementioned signaling proteins the reader is referred to [74].

\section{S. cerevisiae $\Delta$ ncr1 mutants, a model for Niemann Pick type C1}

NPC is a fatal lipid storage disease with progressive neurodegeneration that affects $1 / 150.000$ live births [188]. While neurodegeneration is the most prominent feature of NPC, organs such as the liver, ovaries and lungs also display aberrant lipid storage [189]. NPC is typically caused by mutations in the genes encoding NPC1 and NPC2 accounting for $95 \%$ and $5 \%$ of all cases, respectively [190-192]. NPC1 and NPC2 remove cholesterol from the late endosomes/lysosomes (LE/LY) [191, 192]. Cholesterol is a sterol involved in membrane function modulation and precursor to steroid hormones, oxysterols and vitamin D [193]. NPC1deficient cells tend to accumulate lipids such as cholesterol, glycoSL and Sph in the LE/LY [79, 194, 195]. Despite the facts that the specific mechanisms leading to neurodegeneration in NPC are not well established, mitochondrial dysfunction and oxidative stress are found to be key charac- teristics of NPC [196-200]. Intriguingly, a pharmacological approach targeting glycoSL synthesis alleviates symptoms in NPC animal models [201], however, an underlying effect on mitochondrial function was not addressed. Hence, targeting SL homeostasis might be a promising approach in treatment of NPC.

Given the conservation of NPC1 and NPC2 in eukaryotes, several non-mammalian models are available to study NPC including the model yeast S. cerevisiae [202]. In yeast, Ncr1p (NPC1 related gene 1) is the orthologue of NPC1 [175] and localizes to the membrane of the vacuole [203]. The role of Ncr1p has been described as fundamentally linked to SL homeostasis with sterol movement as a consequence $[175,202]$. Yeast does not synthesize cholesterol, but the structural relative ergosterol [204]. Whether or not the loss of Ncr1p in yeast causes ergosterol accumulation has to be clarified yet, as Malathi and coworkers showed that $\Delta n c r 1$ mutants do not exhibit aberrancies in sterol metabolism [175] while more recently two independent research groups showed the contrary $[205,206]$. Still, intracellular sterol transport has been linked to mitochondrial function in yeast [207]. In contrast to $\Delta n c r 1$ mutants, mutations in the putative sterol-sensing domain of Ncr1p causes several phenotypes such as impaired growth at elevated temperatures, increased salt sensitivity and low growth on acetate and ethanol as carbon source [175]. Such phenotypes were ascribed to alterations in SL metabolism [175], as observed in NPC [79]. Although initial studies with $\Delta$ ncr 1 mutants did not show any observable phenotype specifically related to loss of Ncr1p but rather associated with Ncr1p mutations, Berg and coworkers reported that $\Delta n c r 1$ mutants are resistant to the ether lipid drug edelfosine [208].

Nevertheless, Vilaça and coworkers reported very recently on phenotypes of $\Delta n c r 1$ mutants that at least partly resemble cellular alterations/aspects observed in NPC patients. For instance, $\Delta n c r 1$ mutants display increased hydrogen peroxide sensitivity and shortened CLS, with increased prevalence of oxidative stress markers [205]. Also, their results indicate that $\Delta n c r 1$ mutants display mitochondrial dysfunction as these mutant cells are for instance unable to grow on a non-fermentative carbon source, display decreased $\Delta \psi_{m}$ and mitochondrial fragmentation [205]. In addition, $\Delta n c r 1$ mutants display aberrant SL homeostasis as such mutants accumulate LCBs due to increased turnover of complex SLs [205]. Taken together, in line with NPC [79, 196-200], $\Delta n c r 1$ mutants display markers of oxidative stress, mitochondrial dysfunction and accumulate SLs.

Mitochondrial function in $\Delta n c r 1$ mutants is suggested to be regulated by SLs. Characteristic for $\Delta n c r 1$ mutants is the increased Pkh1p-dependent activation of Sch9p. Concomitantly, $\Delta n c r 1 \Delta p k h 1$ and $\Delta n c r 1 \Delta s c h 9$ mutants display restored mitochondrial function as these double mutants are for instance able to grow on a non-fermentable carbon source [205]. Thus, as suggested for $\Delta i s c 1$ mutants [74], this indicates that Sch9p is involved in regulating mitochondrial function in response to SLs in $\Delta n c r 1$ mutants. Taken together, these results suggest that SLs indeed are 
essential determinants of mitochondrial dysfunction associated with NPC.

Next to the above described study, yeast studies have shed light on new potential targets for treatment of NPC. Munkacsi and coworkers identified 12 pathways and 13 genes that are of importance for growth of $\Delta n c r 1$ mutants during anaerobis in presence of exogenous ergosterol [209]. S. cerevisiae cells become auxotrophic to sterol in absence of oxygen [210]. Based on their results, they hypothesized that histone deacetylation contributes to the pathogenesis of NPC and indeed confirmed this in NPCderived fibroblasts: genes encoding histone deacetylases (HDACS) are upregulated in NPC-derived fibroblasts. Histone deacetylase (HDAC) plays a key role in gene regulation by removing acetyl groups from specific lysine residues on histones, which increases DNA condensation and thus thereby decreases gene expression. The opposite reaction is catalyzed by histone acetyltransferases and this increases gene expression [211, 212]. Intriguingly, Sph kinase 2 (SphK2), one of the two Sph kinase isoforms which mainly localizes to the nucleus [213], has been shown to associate with HDAC1 and HDAC2, two class I HDACs [214], in repressor complexes as well as histone $\mathrm{H} 3$ and thereby increasing $\mathrm{H} 3$ acetylation and transcription. This increase in $\mathrm{H} 3$ acetylation and transcription is attributed to the SphK2dependent Sph-1-P production in the nucleus which directly binds to the active site of HDAC1 and HDAC2, and thereby inhibits their activity and linking SLs to gene expression [215]. In addition, Munkacsi and coworkers could reverse aberrant HDAC function and show concomitant improved NPC characteristics such as decreased accumulation of cholesterol and SLS [209]. In line, HDAC inhibitors were recently suggested as a promising therapeutic in treatment of NPC [216]. Hence, the study by Munckacsi and coworkers indicates that $S$. cerevisiae is a powerful tool to identify novel pathways involved in the pathogenesis of NPC and for selecting novel therapeutic targets and therapies.

\section{S. cerevisiae as a model to study $\mathrm{Cu}$ toxicity in context of Wilson disease}

WD is a relevant human pathology (incidence 1/30.000) caused by mutations in the gene encoding the $\mathrm{Cu}$ transporting ATPase ATP7B resulting in the accumulation of excess $\mathrm{Cu}$ in the liver and increased intracellular $\mathrm{Cu}$ levels [176, 217-219]. This results in acute liver failure or cirrhosis but also neurodegeneration [217, 218, 220]. Interestingly, the yeast $C C C 2$ gene, encoding a P-type $\mathrm{Cu}$ transporting ATPase, is homologous to ATP7B [221]. Cu uptake in yeast is mediated by the high-affinity $\mathrm{Cu}$ transporter Ctr1p [222] and $\mathrm{Cu}$ is subsequently delivered to $\mathrm{Ccc} 2 \mathrm{p}$ by the action of the $\mathrm{Cu}$ metallochaperone Atx $1 p$ [223]. Ccc2p transports $\mathrm{Cu}$ to the Golgi lumen for $\mathrm{Cu}$ incorporation into Fet3p, which is required for iron uptake [224] Loss of $\operatorname{Ccc} 2 p$ results in respiration defects and defective iron uptake $[224,225]$. Also, $\Delta c c c 2$ mutants exhibit defective growth on low iron-containing growth media which can be rescued by overexpression of wild type $A T P 7 B$ or WD-related $A T P 7 B$ mutants [226, 227]. However, $A T P 7 B$ mutants do not restore $\triangle c c c 2$ mutant growth on low iron- containing growth medium to the same extent as wild type ATPB $[226,227]$. Mechanistic events that are characteristic for Cu-induced toxicity in liver cells is Cu-induced mitochondrial dysfunction [6] and Cu-induced increased acid SMase (aSMase) activity [30]. The latter study showed that $\mathrm{Cu}$ increases aSMase acitivity resulting in increased levels of pro-apoptotic Cer [30, 228]. In addition, their results show that aSMase inhibition, either by pharmacological intervention or genetic disruption prevents $\mathrm{Cu}$-induced apoptosis [30]. Interestingly, there is an increased constitutive activation of aSMase in plasma of WD patients. Thus, Cu-induced toxicity is fundamentally linked to mitochondrial dysfunction and aberrant SL metabolism.

We recently showed that the $A$. thaliana-derived decapeptide OSIP108 [229] prevents $\mathrm{Cu}$-induced apoptosis and oxidative stress in yeast and human cells [230], but also prevents $\mathrm{Cu}$-induced hepatotoxicity in a zebrafish larvae model (unpublished data). Based on the observation that OSIP108 pretreatment of HepG2 cells was necessary in order to observe anti-apoptotic effects, we investigated the effect of OSIP108 on SL homeostasis in HepG2 cells and found that OSIP108-treated HepG2 cells displayed decreased levels of sphingoid bases (Sph, Sph-1-P and dhSph1-P), dhCer species $\left(C_{12}\right.$ and $\left.C_{14}\right)$, Cer species $\left(C_{18: 1}\right.$ and $\left.C_{26}\right)$ and SM species $\left(C_{14}, C_{18}, C_{20: 1}\right.$ and $\left.C_{24}\right)$. Of note is that dhSph levels in OSIP108-treated HepG2 cells were also decreased but not to a significant level. These observations led to the hypothesis that OSIP108 might act as a 3ketodihydrosphingosine reductase inhibitor. Hence, we subsequently validated these observations in S. cerevisiae and found that exogenous dhSph addition abolished the protective effect of OSIP108 on Cu-induced toxicity in yeast cells [230]. As exogenous dhSph abolished this protective effect, this suggests that SLs are directly involved in $\mathrm{Cu}$ induced toxicity in yeast and mammalian cells, and that compounds that can rescue $\mathrm{Cu}$-induced toxicity in yeast seem to specifically target SL homeostasis. There is however not yet conclusive evidence to support this hypothesis.

In addition, our ongoing research is aimed at identifying novel compounds that increase yeast tolerance to suggested inducers of mitochondrial dysfunction, including $\mathrm{Cu}$. As such, by screening the Pharmakon 1600 repositioning library, we identified at least 1 class of off-patent drugs that prevent $\mathrm{Cu}$-induced toxicity in yeast (unpublished data). Thus far, this drug class has not been linked to Cu toxicity, nor does their mammalian target have a yeast counterpart. We are currently translating these data to a higher eukaryotic setting. Hence, this indicates that our $\mathrm{Cu}$ toxicity yeast screen can result in the identification of new novel therapeutic options and unknown targets in treatment of, for instance, WD.

\section{CONCLUSION}

In conclusion, several studies in S. cerevisiae indicate an important signaling role for SLs in maintaining correct $\mathrm{mi}-$ tochondrial function. These data were confirmed in relevant mammalian models for pathologies characterized by mitochondrial dysfunction. More specifically, knowledge 
on the link between SLs and mitochondrial function generated in the model yeast $S$. cerevisiae advanced research in particular diseases such as WD and NPC. In addition, using yeast as screening model for these diseases, development of novel therapies seems feasible and promising.

Noteworthy is, however, that different SL species clearly have different roles as exemplified by the differential effect of Cer species with different chain length on the induction of the mitochondrial surveillance pathway in $C$. elegans [164]. Moreover, the differential role of Cer species with different chain length in human diseases was discussed recently [231]. As for yeast research, the study by Montefusco and coworkers showed that specific groups of Cer species that vary in side chain and hydroxylation coordinate different sets of functionally related genes [148]. Thus, besides the fact that different Cer species are subjected to regulation by specific biochemical pathways in specific subcellular compartments, they also serve distinct roles, which was discussed previously by Hannun and Obeid [89]. In the latter review article, the interconnectivity of the SL metabolism was also highlighted, given the fact that manipulating one enzyme involved in SL metabolism not only leads to the perturbation of its derived SL metabolite, but also to downstream derived SL species, denoted as the 'metabolic ripple effect'. Hence, despite our extensive knowledge on SL metabolism and functioning, the concept of many ceramides and the interconnectivity of SL metabo- lism introduces additional complexity in tackling the roles for specific SL species in SL signaling.

In conclusion, basic yeast research has provided important clues for SL signaling events that impact on mitochondrial function, in higher eukaryotic and mammalian cells, as well as for novel therapeutic options for diseases in which mitochondrial dysfunction is critical.

\section{ACKNOWLEDGMENTS}

P.S. is supported by IWT-Vlaanderen and K.T. by 'Industrial Research Fund' of KU Leuven (IOF-M).

\section{CONFLICT OF INTEREST}

The authors declare no conflict of interest.

\section{COPYRIGHT}

(C) 2014 Spincemaille et al. This is an open-access article released under the terms of the Creative Commons Attribution (CC BY) license, which allows the unrestricted use, distribution, and reproduction in any medium, provided the original author and source are acknowledged.

Please cite this article as: Pieter Spincemaille, Bruno P.A. Cammue and Karin Thevissen (2014). Sphingolipids and mitochondrial function, lessons learned from yeast. Microbial Cell 1(7): 210-224. doi: 10.15698/mic2014.07.156

\section{REFERENCES}

1. Hsu CC, Lee HC, Wei YH (2013). Mitochondrial DNA alterations and mitochondrial dysfunction in the progression of hepatocellular carcinoma. World journal of gastroenterology : WJG 19(47): 88808886.

2. Boland ML, Chourasia AH, Macleod KF (2013). Mitochondrial Dysfunction in Cancer. Frontiers in oncology 3:292.

3. Zuo L, Motherwell MS (2013). The impact of reactive oxygen species and genetic mitochondrial mutations in Parkinson's disease. Gene 532(1): 18-23.

4. Sery O, Povova J, Misek I, Pesak L, Janout V (2013). Molecular mechanisms of neuropathological changes in Alzheimer's disease: a review. Folia neuropathologica / Association of Polish Neuropathologists and Medical Research Centre, Polish Academy of Sciences 51(1): 1-9.

5. Gonzalez-Cabo P, Palau F (2013). Mitochondrial pathophysiology in Friedreich's ataxia. Journal of neurochemistry 126 Suppl 1:53-64.

6. Zischka H, Lichtmannegger J (2014). Pathological mitochondrial copper overload in livers of Wilson's disease patients and related animal models. Annals of the New York Academy of Sciences. 1315(1):6-15.

7. Verbeek J, Lannoo M, Pirinen E, Ryu D, Spincemaille P, van der Elst I, Windmolders $\mathrm{P}$, Thevissen $\mathrm{K}$, Cammue BPA, van Pelt J, Fransis S, Van Eyken P, Ceuterick-De Groote C, Van Veldhoven PP, Bedossa P, Nevens F, Auwerx J, Cassiman D (2014). Roux-en-y gastric bypass attenuates hepatic mitochondrial dysfunction in mice with nonalcoholic steatohepatitis. Gut In Press.

8. Begriche K, Igoudjil A, Pessayre D, Fromenty B (2006). Mitochondrial dysfunction in $\mathrm{NASH}$ : causes, consequences and possible means to prevent it. Mitochondrion 6(1): 1-28.

9. Serviddio G, Bellanti F, Vendemiale G, Altomare E (2011). Mitochondrial dysfunction in nonalcoholic steatohepatitis. Expert review of gastroenterology \& hepatology 5(2): 233-244.

10. Nicolson GL (2007). Metabolic syndrome and mitochondrial function: molecular replacement and antioxidant supplements to prevent membrane peroxidation and restore mitochondrial function. Journal of cellular biochemistry 100(6): 1352-1369.

11. Stiles L, Shirihai OS (2012). Mitochondrial dynamics and morphology in beta-cells. Best practice \& research Clinical endocrinology \& metabolism 26(6): 725-738.

12. Han D, Dara L, Win S, Than TA, Yuan L, Abbasi SQ, Liu ZX, Kaplowitz $N$ (2013). Regulation of drug-induced liver injury by signal transduction pathways: critical role of mitochondria. Trends in pharmacological sciences 34(4): 243-253.

13. Pessayre D, Fromenty B, Berson A, Robin MA, Letteron P, Moreau $R$, Mansouri $A$ (2012). Central role of mitochondria in drug-induced liver injury. Drug metabolism reviews 44(1): 34-87.

14. Schon EA, DiMauro S, Hirano M (2012). Human mitochondrial DNA: roles of inherited and somatic mutations. Nature reviews Genetics 13(12): 878-890.

15. Schapira AH (2012). Mitochondrial diseases. Lancet 379(9828): 1825-1834.

16. Biniecka M, Fox E, Gao W, Ng CT, Veale DJ, Fearon U, O'Sullivan J (2011). Hypoxia induces mitochondrial mutagenesis and dysfunction in inflammatory arthritis. Arthritis and rheumatism 63(8): 2172-2182. 
17. Kazachkova N, Ramos A, Santos C, Lima M (2013). Mitochondrial DNA damage patterns and aging: revising the evidences for humans and mice. Aging and disease 4(6): 337-350.

18. Lopez-Otin C, Blasco MA, Partridge L, Serrano M, Kroemer G (2013). The hallmarks of aging. Cell 153(6): 1194-1217.

19. Sharma H, Singh A, Sharma C, Jain SK, Singh N (2005). Mutations in the mitochondrial DNA D-loop region are frequent in cervical cancer. Cancer cell international 5:34

20. Wei YH, Lee HC (2002). Oxidative stress, mitochondrial DNA mutation, and impairment of antioxidant enzymes in aging. Experimental biology and medicine 227(9): 671-682.

21. Birch-Machin MA, Swalwell H (2010). How mitochondria record the effects of UV exposure and oxidative stress using human skin as a model tissue. Mutagenesis 25(2): 101-107.

22. Gorman S, Fox E, O'Donoghue D, Sheahan K, Hyland J, Mulcahy H, Loeb LA, O'Sullivan J (2010). Mitochondrial mutagenesis induced by tumor-specific radiation bystander effects. Journal of molecular medicine 88(7): 701-708.

23. Cohen BH, Gold DR (2001). Mitochondrial cytopathy in adults: what we know so far. Cleveland Clinic journal of medicine 68(7): 625$626,629-642$.

24. Vernon SD, Whistler T, Cameron B, Hickie IB, Reeves WC, Lloyd A (2006). Preliminary evidence of mitochondrial dysfunction associated with post-infective fatigue after acute infection with Epstein Barr virus. BMC infectious diseases 6:15.

25. Meyer JN, Leung MC, Rooney JP, Sendoel A, Hengartner MO, Kisby $\mathrm{GE}$, Bess AS (2013). Mitochondria as a target of environmental toxicants. Toxicological sciences : an official journal of the Society of Toxicology 134(1): 1-17.

26. Goldkorn T, Chung S, Filosto S (2013). Lung cancer and lung injury: the dual role of ceramide. Handbook of experimental pharmacology 216: 93-113.

27. Heffernan-Stroud LA, Obeid LM (2013). Sphingosine kinase 1 in cancer. Advances in cancer research 117:201-235.

28. Morad SA, Cabot MC (2013). Ceramide-orchestrated signalling in cancer cells. Nature reviews Cancer 13(1): 51-65.

29. Yuyama K, Mitsutake S, Igarashi Y (2013). Pathological roles of ceramide and its metabolites in metabolic syndrome and Alzheimer's disease. Biochimica et biophysica acta. 184(5): 793-8

30. Lang PA, Schenck M, Nicolay JP, Becker JU, Kempe DS, Lupescu A Koka S, Eisele K, Klarl BA, Rubben H, Schmid KW, Mann K, Hildenbrand $S$, Hefter $H$, Huber SM, Wieder T, Erhardt A, Haussinger D, Gulbins E, Lang $F$ (2007). Liver cell death and anemia in Wilson disease involve acid sphingomyelinase and ceramide. Nature medicine 13(2): 164170

31. Galadari S, Rahman A, Pallichankandy S, Galadari A, Thayyullathil F (2013). Role of ceramide in diabetes mellitus: evidence and mechanisms. Lipids in health and disease 12:98.

32. Supale S, Li N, Brun T, Maechler P (2012). Mitochondrial dysfunction in pancreatic beta cells. Trends in endocrinology and metabolism: TEM 23(9): 477-487.

33. van Echten-Deckert G, Walter J (2012). Sphingolipids: critical players in Alzheimer's disease. Progress in lipid research 51(4): 378393

34. Vamecq J, Dessein AF, Fontaine M, Briand G, Porchet N, Latruffe N, Andreolotti $P$, Cherkaoui-Malki M (2012). Mitochondrial dysfunction and lipid homeostasis. Current drug metabolism 13(10): 1388-1400.
35. Chiantia S, London E (2013). Sphingolipids and membrane domains: recent advances. Handbook of experimental pharmacology 215: 33-55.

36. Spiegel S, Merrill AH, Jr. (1996). Sphingolipid metabolism and cell growth regulation. FASEB journal : official publication of the Federation of American Societies for Experimental Biology 10(12): 1388-1397.

37. Young MM, Kester M, Wang HG (2013). Sphingolipids: regulators of crosstalk between apoptosis and autophagy. Journal of lipid research 54(1): 5-19.

38. Smith WL, Merrill AH, Jr. (2002). Sphingolipid metabolism and signaling minireview series. The Journal of biological chemistry 277(29): 25841-25842.

39. Goffeau A, Barrell BG, Bussey H, Davis RW, Dujon B, Feldmann H, Galibert F, Hoheisel JD, Jacq C, Johnston M, Louis EJ, Mewes HW, Murakami Y, Philippsen P, Tettelin H, Oliver SG (1996). Life with 6000 genes. Science 274(5287): 546, 563-547.

40. Foury F, Roganti T, Lecrenier N, Purnelle B (1998). The complete sequence of the mitochondrial genome of Saccharomyces cerevisiae. FEBS letters 440(3): 325-331.

41. Anderson $S$, Bankier AT, Barrell BG, de Bruijn $M H$, Coulson AR, Drouin J, Eperon IC, Nierlich DP, Roe BA, Sanger F, Schreier PH, Smith AJ, Staden R, Young IG (1981). Sequence and organization of the human mitochondrial genome. Nature 290(5806): 457-465.

42. Wallace DC, Singh G, Lott MT, Hodge JA, Schurr TG, Lezza AM, Elsas L, 2nd, Nikoskelainen EK (1988). Mitochondrial DNA mutation associated with Leber's hereditary optic neuropathy. Science 242(4884): 1427-1430.

43. Kirches E (2011). LHON: Mitochondrial Mutations and More. Current genomics 12(1): 44-54.

44. Botstein D, Chervitz SA, Cherry JM (1997). Yeast as a model organism. Science 277(5330): 1259-1260.

45. Foury $F$ (1997). Human genetic diseases: a cross-talk between man and yeast. Gene 195(1): 1-10.

46. Bassett DE, Jr., Boguski MS, Hieter P (1996). Yeast genes and human disease. Nature 379(6566): 589-590.

47. Frohlich KU, Fussi H, Ruckenstuhl C (2007). Yeast apoptosis--from genes to pathways. Seminars in cancer biology 17(2): 112-121.

48. Rea SL, Graham BH, Nakamaru-Ogiso E, Kar A, Falk MJ (2010). Bacteria, yeast, worms, and flies: exploiting simple model organisms to investigate human mitochondrial diseases. Developmental disabilities research reviews 16(2): 200-218.

49. Barrientos A (2003). Yeast models of human mitochondrial diseases. IUBMB life 55(2): 83-95.

50. Foury F, Kucej M (2002). Yeast mitochondrial biogenesis: a model system for humans? Current opinion in chemical biology 6(1): 106111.

51. Baile MG, Claypool SM (2013). The power of yeast to model diseases of the powerhouse of the cell. Frontiers in bioscience 18: 241-278.

52. Hannun YA, Luberto C, Argraves KM (2001). Enzymes of sphingolipid metabolism: from modular to integrative signaling. Biochemistry 40(16): 4893-4903.

53. van der Bliek AM, Shen $Q$, Kawajiri S (2013). Mechanisms of mitochondrial fission and fusion. Cold Spring Harbor perspectives in biology 5(6).

54. Youle RJ, van der Bliek AM (2012). Mitochondrial fission, fusion, and stress. Science 337(6098): 1062-1065. 
55. Horvath SE, Daum G (2013). Lipids of mitochondria. Progress in lipid research 52(4): 590-614.

56. Chinnery PF, Schon EA (2003). Mitochondria. Journal of neurology, neurosurgery, and psychiatry 74(9): 1188-1199.

57. Camara AK, Lesnefsky EJ, Stowe DF (2010). Potential therapeutic benefits of strategies directed to mitochondria. Antioxidants \& redox signaling 13(3): 279-347.

58. Pelicano H, Martin DS, Xu RH, Huang P (2006). Glycolysis inhibition for anticancer treatment. Oncogene 25(34): 4633-4646.

59. Bayley JP, Devilee P (2012). The Warburg effect in 2012. Current opinion in oncology 24(1): 62-67.

60. Warburg O, Wind F, Negelein E (1927). The Metabolism of Tumors in the Body. The Journal of general physiology 8(6): 519-530.

61. Ring J, Sommer C, Carmona-Gutierrez D, Ruckenstuhl C, Eisenberg $T$, Madeo $F$ (2012). The metabolism beyond programmed cell death in yeast. Experimental cell research 318(11): 1193-1200.

62. Ruckenstuhl C, Buttner S, Carmona-Gutierrez D, Eisenberg T, Kroemer G, Sigrist SJ, Frohlich KU, Madeo F (2009). The Warburg effect suppresses oxidative stress induced apoptosis in a yeast model for cancer. PloS one 4(2): e4592.

63. Karlsson KA (1970). Sphingolipid long chain bases. Lipids 5(11): 878-891. PMID: 4921900.

64. Bartke N, Hannun YA (2009). Bioactive sphingolipids: metabolism and function. Journal of lipid research 50 Suppl S91-96.

65. Zheng W, Kollmeyer J, Symolon $H$, Momin A, Munter $E$, Wang $E$, Kelly S, Allegood JC, Liu Y, Peng Q, Ramaraju H, Sullards MC, Cabot M, Merrill AH, Jr. (2006). Ceramides and other bioactive sphingolipid backbones in health and disease: lipidomic analysis, metabolism and roles in membrane structure, dynamics, signaling and autophagy. Biochimica et biophysica acta 1758(12): 1864-1884.

66. Hannun YA, Obeid LM (2008). Principles of bioactive lipid signalling: lessons from sphingolipids. Nature reviews Molecular cell biology 9(2): 139-150.

67. Kogot-Levin A, Saada A (2014). Ceramide and the mitochondrial respiratory chain. Biochimie 100:88-94.

68. Vaena de Avalos S, Okamoto Y, Hannun YA (2004). Activation and localization of inositol phosphosphingolipid phospholipase C, Isc1p, to the mitochondria during growth of Saccharomyces cerevisiae. The Journal of biological chemistry 279(12): 11537-11545.

69. Barbosa AD, Graca J, Mendes V, Chaves SR, Amorim MA, Mendes MV, Moradas-Ferreira P, Corte-Real M, Costa V (2012). Activation of the Hog $1 p$ kinase in Isc1p-deficient yeast cells is associated with mitochondrial dysfunction, oxidative stress sensitivity and premature aging. Mechanisms of ageing and development 133(5): 317-330.

70. Almeida T, Marques M, Mojzita D, Amorim MA, Silva RD, Almeida $B$, Rodrigues $P$, Ludovico P, Hohmann S, Moradas-Ferreira P, CorteReal $M$, Costa $V$ (2008). Isc1p plays a key role in hydrogen peroxide resistance and chronological lifespan through modulation of iron levels and apoptosis. Molecular biology of the cell 19(3): 865-876.

71. Vaena de Avalos S, Su X, Zhang M, Okamoto Y, Dowhan W, Hannun YA (2005). The phosphatidylglycerol/cardiolipin biosynthetic pathway is required for the activation of inositol phosphosphingolipid phospholipase C, Isc1p, during growth of Saccharomyces cerevisiae. The Journal of biological chemistry 280(8): 7170-7177.

72. Teixeira V, Medeiros, T.C., Vilaça, R., Moradas-Ferreira, P., and Costa, V. (2014). Reduced TORC1 signaling abolishes mitochondrial dysfunctions and shortened chronological lifespan of Isc1p-deficient cells. Microbial Cell 1(1): 21-36.
73. Rego A, Costa M, Chaves SR, Matmati N, Pereira H, Sousa MJ, Moradas-Ferreira P, Hannun YA, Costa V, Corte-Real M (2012). Modulation of mitochondrial outer membrane permeabilization and apoptosis by ceramide metabolism. PloS one 7(11): e48571.

74. Spincemaille $P$, Matmati N, Hannun YA, Cammue BPA, Thevissen K (2014). Sphingolipids and Mitochondrial Function in Budding Yeast. Biochimica et biophysica acta In press.

75. Bielawski J, Pierce JS, Snider J, Rembiesa B, Szulc ZM, Bielawska A (2010). Sphingolipid analysis by high performance liquid chromatography-tandem mass spectrometry (HPLC-MS/MS). Advances in experimental medicine and biology 688:46-59.

76. Bielawski J, Szulc ZM, Hannun YA, Bielawska A (2006). Simultaneous quantitative analysis of bioactive sphingolipids by highperformance liquid chromatography-tandem mass spectrometry. Methods 39(2): 82-91.

77. Yamagata M, Obara K, Kihara A (2011). Sphingolipid synthesis is involved in autophagy in Saccharomyces cerevisiae. Biochemical and biophysical research communications 410(4): 786-791.

78. Huang X, Liu J, Dickson RC (2012). Down-regulating sphingolipid synthesis increases yeast lifespan. PLoS genetics 8(2): e1002493.

79. Lloyd-Evans E, Morgan AJ, He X, Smith DA, Elliot-Smith E, Sillence DJ, Churchill GC, Schuchman EH, Galione A, Platt FM (2008). NiemannPick disease type $\mathrm{C} 1$ is a sphingosine storage disease that causes deregulation of lysosomal calcium. Nature medicine 14(11): 12471255 .

80. Tong $\mathrm{M}$, Longato $\mathrm{L}$, Ramirez $\mathrm{T}$, Zabala $\mathrm{V}$, Wands JR, de la Monte SM (2014). Therapeutic reversal of chronic alcohol-related steatohepatitis with the ceramide inhibitor myriocin. International journal of experimental pathology 95(1): 49-63.

81. Kurek K, Piotrowska DM, Wiesiolek-Kurek P, Lukaszuk B, Chabowski A, Gorski J, Zendzian-Piotrowska M (2013). Inhibition of ceramide de novo synthesis reduces liver lipid accumulation in rats with nonalcoholic fatty liver disease. Liver international : official journal of the International Association for the Study of the Liver.

82. Kajiwara K, Muneoka T, Watanabe $\mathrm{Y}$, Karashima $\mathrm{T}$, Kitagaki $\mathrm{H}$, Funato $K$ (2012). Perturbation of sphingolipid metabolism induces endoplasmic reticulum stress-mediated mitochondrial apoptosis in budding yeast. Molecular microbiology 86(5): 1246-1261.

83. Cerantola V, Guillas I, Roubaty C, Vionnet C, Uldry D, Knudsen J, Conzelmann A (2009). Aureobasidin A arrests growth of yeast cells through both ceramide intoxication and deprivation of essential inositolphosphorylceramides. Molecular microbiology 71(6): 15231537.

84. Lee S, Gaspar ML, Aregullin MA, Jesch SA, Henry SA (2013). Activation of protein kinase C-mitogen-activated protein kinase signaling in response to inositol starvation triggers Sir2p-dependent telomeric silencing in yeast. The Journal of biological chemistry 288(39): 27861-27871.

85. Jenkins GM, Cowart LA, Signorelli $P$, Pettus BJ, Chalfant CE, Hannun YA (2002). Acute activation of de novo sphingolipid biosynthesis upon heat shock causes an accumulation of ceramide and subsequent dephosphorylation of SR proteins. The Journal of biological chemistry 277(45): 42572-42578.

86. Shimabukuro M, Zhou YT, Levi M, Unger RH (1998). Fatty acidinduced beta cell apoptosis: a link between obesity and diabetes. Proceedings of the National Academy of Sciences of the United States of America 95(5): 2498-2502.

87. Rego A, Trindade D, Chaves SR, Manon S, Costa V, Sousa MJ, Corte-Real M (2013). The yeast model system as a tool towards the understanding of apoptosis regulation by sphingolipids. FEMS yeast research. 14(1): 160-178. 
88. Sims KJ, Spassieva SD, Voit EO, Obeid LM (2004). Yeast sphingolipid metabolism: clues and connections. Biochemistry and cell biology 82(1): 45-61.

89. Hannun YA, Obeid LM (2011). Many ceramides. The Journal of biological chemistry 286(32): 27855-27862.

90. Hanada K (2003). Serine palmitoyltransferase, a key enzyme of sphingolipid metabolism. Biochimica et biophysica acta 1632(1-3): 1630.

91. Kihara A, Igarashi $Y$ (2004). FVT-1 is a mammalian 3ketodihydrosphingosine reductase with an active site that faces the cytosolic side of the endoplasmic reticulum membrane. The Journal of biological chemistry 279(47): 49243-49250.

92. Mullen TD, Hannun YA, Obeid LM (2012). Ceramide synthases at the centre of sphingolipid metabolism and biology. The Biochemical journal 441(3): 789-802

93. Fabrias G, Munoz-Olaya J, Cingolani F, Signorelli P, Casas J, Gagliostro V, Ghidoni R (2012). Dihydroceramide desaturase and dihydrosphingolipids: debutant players in the sphingolipid arena. Progress in lipid research 51(2): 82-94

94. Mao C, Obeid LM (2008). Ceramidases: regulators of cellular responses mediated by ceramide, sphingosine, and sphingosine-1phosphate. Biochimica et biophysica acta 1781(9): 424-434.

95. Sugiura $M$, Kono $K$, Liu $H$, Shimizugawa $T$, Minekura $H$, Spiegel $S$, Kohama T (2002). Ceramide kinase, a novel lipid kinase. Molecular cloning and functional characterization. The Journal of biological chemistry 277(26): 23294-23300.

96. Holthuis JC, Luberto C (2010). Tales and mysteries of the enigmatic sphingomyelin synthase family. Advances in experimental medicine and biology 688:72-85.

97. Ichikawa S, Hirabayashi Y (1998). Glucosylceramide synthase and glycosphingolipid synthesis. Trends in cell biology 8(5): 198-202.

98. Sprong H, Kruithof B, Leijendekker R, Slot JW, van Meer G, van der Sluijs $P$ (1998). UDP-galactose:ceramide galactosyltransferase is a class I integral membrane protein of the endoplasmic reticulum. The Journal of biological chemistry 273(40): 25880-25888.

99. Basu S, Kaufman B, Roseman S (1968). Enzymatic synthesis of ceramide-glucose and ceramide-lactose by glycosyltransferases from embryonic chicken brain. The Journal of biological chemistry 243(21): 5802-5804.

100. Slotte JP (2013). Biological functions of sphingomyelins. Progress in lipid research 52(4): 424-437.

101. Hakomori SI (2008). Structure and function of glycosphingolipids and sphingolipids: recollections and future trends. Biochimica et biophysica acta 1780(3): 325-346.

102. D'Angelo G, Capasso S, Sticco L, Russo D (2013). Glycosphingolipids: synthesis and functions. The FEBS journal 280(24): 6338-6353.

103. Hakomori S, Igarashi Y (1995). Functional role of glycosphingolipids in cell recognition and signaling. Journal of biochemistry 118(6): 1091-1103.

104. Lingwood CA (2011). Glycosphingolipid functions. Cold Spring Harbor perspectives in biology $3(7)$.

105. Hruska KS, LaMarca ME, Scott CR, Sidransky E (2008). Gaucher disease: mutation and polymorphism spectrum in the glucocerebrosidase gene (GBA). Human mutation 29(5): 567-583.

106. Luzi P, Rafi MA, Wenger DA (1995). Structure and organization of the human galactocerebrosidase (GALC) gene. Genomics 26(2): 407409.
107. Omae F, Miyazaki M, Enomoto A, Suzuki A (2004). Identification of an essential sequence for dihydroceramide $C-4$ hydroxylase activity of mouse DES2. FEBS letters 576(1-2): 63-67.

108. Omae F, Miyazaki M, Enomoto A, Suzuki M, Suzuki Y, Suzuki A (2004). DES2 protein is responsible for phytoceramide biosynthesis in the mouse small intestine. The Biochemical journal 379(Pt 3): $687-$ 695.

109. Goni FM, Alonso A (2002). Sphingomyelinases: enzymology and membrane activity. FEBS letters 531(1): 38-46.

110. Hait NC, Oskeritzian CA, Paugh SW, Milstien S, Spiegel S (2006). Sphingosine kinases, sphingosine 1-phosphate, apoptosis and diseases. Biochimica et biophysica acta 1758(12): 2016-2026.

111. Bourquin F, Riezman H, Capitani G, Grutter MG (2010). Structure and function of sphingosine-1-phosphate lyase, a key enzyme of sphingolipid metabolism. Structure 18(8): 1054-1065.

112. Ogawa C, Kihara A, Gokoh M, Igarashi Y (2003). Identification and characterization of a novel human sphingosine-1-phosphate phosphohydrolase, hSPP2. The Journal of biological chemistry $278(2)$ : 1268-1272.

113. Van Veldhoven PP, Gijsbers S, Mannaerts GP, Vermeesch JR, Brys $\mathrm{V}$ (2000). Human sphingosine-1-phosphate lyase: cDNA cloning, functional expression studies and mapping to chromosome 10q22(1). Biochimica et biophysica acta 1487(2-3): 128-134.

114. Mandala SM, Thornton R, Galve-Roperh I, Poulton S, Peterson C Olivera A, Bergstrom J, Kurtz MB, Spiegel S (2000). Molecular cloning and characterization of a lipid phosphohydrolase that degrades sphingosine-1- phosphate and induces cell death. Proceedings of the National Academy of Sciences of the United States of America 97(14): 7859-7864.

115. Brindley DN, Xu J, Jasinska R, Waggoner DW (2000). Analysis of ceramide 1-phosphate and sphingosine-1-phosphate phosphatase activities. Methods in enzymology 311:233-244.

116. Haak D, Gable K, Beeler T, Dunn T (1997). Hydroxylation of Saccharomyces cerevisiae ceramides requires Sur $2 p$ and Scs7p. The Journal of biological chemistry 272(47): 29704-29710.

117. Schorling S, Vallee B, Barz WP, Riezman H, Oesterhelt D (2001). Lag1p and Lac1p are essential for the Acyl-CoA-dependent ceramide synthase reaction in Saccharomyces cerevisae. Molecular biology of the cell 12(11): 3417-3427.

118. Mao C, Xu R, Bielawska A, Szulc ZM, Obeid LM (2000). Cloning and characterization of a Saccharomyces cerevisiae alkaline ceramidase with specificity for dihydroceramide. The Journal of biological chemistry 275(40): 31369-31378.

119. Mao C, Xu R, Bielawska A, Obeid LM (2000). Cloning of an alkaline ceramidase from Saccharomyces cerevisiae. An enzyme with reverse (CoA-independent) ceramide synthase activity. The Journal of biological chemistry 275(10): 6876-6884.

120. Fischl AS, Liu Y, Browdy A, Cremesti AE (2000). Inositolphosphoryl ceramide synthase from yeast. Methods in enzymology 311:123-130.

121. Uemura S, Kihara A, Inokuchi J, Igarashi Y (2003). Csg1p and newly identified Csh1p function in mannosylinositol phosphorylceramide synthesis by interacting with Csg2p. The Journal of biological chemistry 278(46): 45049-45055.

122. Dickson RC, Nagiec EE, Wells GB, Nagiec MM, Lester RL (1997) Synthesis of mannose-(inositol-P)2-ceramide, the major sphingolipid in Saccharomyces cerevisiae, requires the IPT1 (YDR072c) gene. The Journal of biological chemistry 272(47): 29620-29625. 
123. Sawai H, Okamoto $\mathrm{Y}$, Luberto $\mathrm{C}$, Mao C, Bielawska A, Domae $\mathrm{N}$ Hannun YA (2000). Identification of ISC1 (YER019w) as inosito phosphosphingolipid phospholipase $\mathrm{C}$ in Saccharomyces cerevisiae. The Journal of biological chemistry 275(50): 39793-39798.

124. Matmati N, Hannun YA (2008). Thematic review series: sphingolipids. Isc1 (inositol phosphosphingolipid-phospholipase C), the yeast homologue of neutral sphingomyelinases. Journal of lipid research 49(5): 922-928.

125. Nagiec MM, Skrzypek M, Nagiec EE, Lester RL, Dickson RC (1998). The LCB4 (YOR171c) and LCB5 (YLR260w) genes of Saccharomyces encode sphingoid long chain base kinases. The Journal of biological chemistry 273(31): 19437-19442.

126. Mao C, Wadleigh M, Jenkins GM, Hannun YA, Obeid LM (1997). Identification and characterization of Saccharomyces cerevisiae dihydrosphingosine-1-phosphate phosphatase. The Journal of biological chemistry 272(45): 28690-28694.

127. Qie L, Nagiec MM, Baltisberger JA, Lester RL, Dickson RC (1997). Identification of a Saccharomyces gene, $L C B 3$, necessary for incorporation of exogenous long chain bases into sphingolipids. The Journal of biological chemistry 272(26): 16110-16117.

128. Mandala SM, Thornton R, Tu Z, Kurtz MB, Nickels J, Broach J, Menzeleev R, Spiegel S (1998). Sphingoid base 1-phosphate phosphatase: a key regulator of sphingolipid metabolism and stress response. Proceedings of the National Academy of Sciences of the United States of America 95(1): 150-155.

129. Saba JD, Nara F, Bielawska A, Garrett S, Hannun YA (1997). The BST1 gene of Saccharomyces cerevisiae is the sphingosine-1phosphate lyase. The Journal of biological chemistry 272(42): 26087 26090.

130. Montefusco DJ, Matmati N, Hannun YA (2014). The yeast sphingolipid signaling landscape. Chemistry and physics of lipids 177: $26-40$.

131. Kluepfel D, Bagli J, Baker H, Charest MP, Kudelski A (1972). Myriocin, a new antifungal antibiotic from Myriococcum albomyces. The Journal of antibiotics 25(2): 109-115.

132. Takesako K, Kuroda H, Inoue T, Haruna F, Yoshikawa Y, Kato I, Uchida K, Hiratani T, Yamaguchi H (1993). Biological properties of aureobasidin A, a cyclic depsipeptide antifungal antibiotic. The Journal of antibiotics 46(9): 1414-1420.

133. Gelderblom WC, Jaskiewicz K, Marasas WF, Thiel PG, Horak RM, Vleggaar R, Kriek NP (1988). Fumonisins-novel mycotoxins with cancer-promoting activity produced by Fusarium moniliforme. Applied and environmental microbiology 54(7): 1806-1811.

134. Wadsworth JM, Clarke DJ, McMahon SA, Lowther JP, Beattie AE, Langridge-Smith PR, Broughton HB, Dunn TM, Naismith JH, Campopiano DJ (2013). The chemical basis of serine palmitoyltransferase inhibition by myriocin. Journal of the American Chemical Society 135(38): 14276-14285.

135. Chen JK, Lane WS, Schreiber SL (1999). The identification of myriocin-binding proteins. Chemistry \& biology 6(4): 221-235.

136. Lowther J, Naismith JH, Dunn TM, Campopiano DJ (2012). Structural, mechanistic and regulatory studies of serine palmitoyltransferase. Biochemical Society transactions 40(3): 547554

137. Heidler SA, Radding JA (1995). The AUR1 gene in Saccharomyces cerevisiae encodes dominant resistance to the antifungal agent aureobasidin A (LY295337). Antimicrobial agents and chemotherapy 39(12): 2765-2769.
138. Stockmann-Juvala $H$, Savolainen $K(\mathbf{2 0 0 8})$. A review of the toxic effects and mechanisms of action of fumonisin B1. Human \& experimental toxicology 27(11): 799-809.

139. Wu WI, McDonough VM, Nickels JT, Jr., Ko J, Fischl AS, Vales TR, Merrill AH, Jr., Carman GM (1995). Regulation of lipid biosynthesis in Saccharomyces cerevisiae by fumonisin B1. The Journal of biological chemistry 270(22): 13171-13178.

140. Shin DY, Matsumoto K, lida H, Uno I, Ishikawa T (1987). Heat shock response of Saccharomyces cerevisiae mutants altered in cyclic AMP-dependent protein phosphorylation. Molecular and cellular biology 7(1): 244-250.

141. Rowley A, Johnston GC, Butler B, Werner-Washburne M, Singer RA (1993). Heat shock-mediated cell cycle blockage and G1 cyclin expression in the yeast Saccharomyces cerevisiae. Molecular and cellular biology 13(2): 1034-1041.

142. Dickson RC, Nagiec EE, Skrzypek M, Tillman P, Wells GB, Lester RL (1997). Sphingolipids are potential heat stress signals in Saccharomyces. The Journal of biological chemistry 272(48): 3019630200.

143. De Virgilio C, Hottiger T, Dominguez J, Boller T, Wiemken A (1994). The role of trehalose synthesis for the acquisition of thermotolerance in yeast. I. Genetic evidence that trehalose is a thermoprotectant. European journal of biochemistry / FEBS 219(1-2): 179-186.

144. Vuorio OE, Kalkkinen N, Londesborough J (1993). Cloning of two related genes encoding the $56-\mathrm{kDa}$ and $123-\mathrm{kDa}$ subunits of trehalose synthase from the yeast Saccharomyces cerevisiae. European journal of biochemistry / FEBS 216(3): 849-861.

145. Jenkins GM, Richards A, Wahl T, Mao C, Obeid L, Hannun Y (1997). Involvement of yeast sphingolipids in the heat stress response of Saccharomyces cerevisiae. The Journal of biological chemistry 272(51): 32566-32572.

146. Jenkins GM, Hannun YA (2001). Role for de novo sphingoid base biosynthesis in the heat-induced transient cell cycle arrest of Saccharomyces cerevisiae. The Journal of biological chemistry 276(11): 8574-8581.

147. Cowart LA, Okamoto Y, Lu X, Hannun YA (2006). Distinct roles for de novo versus hydrolytic pathways of sphingolipid biosynthesis in Saccharomyces cerevisiae. The Biochemical journal 393(Pt 3): 733740.

148. Montefusco DJ, Chen L, Matmati N, Lu S, Newcomb B, Cooper GF Hannun YA, Lu X (2013). Distinct signaling roles of ceramide species in yeast revealed through systematic perturbation and systems biology analyses. Science signaling 6(299): rs14.

149. Dixon SJ, Stockwell BR (2014). The role of iron and reactive oxygen species in cell death. Nature chemical biology 10(1): 9-17.

150. Lee YJ, Huang X, Kropat J, Henras A, Merchant SS, Dickson RC, Chanfreau GF (2012). Sphingolipid signaling mediates iron toxicity. Cell metabolism 16(1): 90-96.

151. Casamayor A, Torrance PD, Kobayashi T, Thorner J, Alessi DR (1999). Functional counterparts of mammalian protein kinases PDK1 and SGK in budding yeast. Current biology : CB 9(4): 186-197.

152. Chen $P$, Lee KS, Levin DE (1993). A pair of putative protein kinase genes (YPK1 and YPK2) is required for cell growth in Saccharomyces cerevisiae. Molecular \& general genetics : MGG 236(2-3): 443-447.

153. Dickson RC (2008). Thematic review series: sphingolipids. New insights into sphingolipid metabolism and function in budding yeast. Journal of lipid research 49(5): 909-921. 
154. Dickson RC (2010). Roles for sphingolipids in Saccharomyces cerevisiae. Advances in experimental medicine and biology 688:217231.

155. Dickson RC, Sumanasekera C, Lester RL (2006). Functions and metabolism of sphingolipids in Saccharomyces cerevisiae. Progress in lipid research 45(6): 447-465.

156. Epstein S, Riezman H (2013). Sphingolipid signaling in yeast: potential implications for understanding disease. Front Biosci (Elite Ed) 5:97-108.

157. Kemmer D, McHardy LM, Hoon S, Reberioux D, Giaever G, Nislow C, Roskelley CD, Roberge M (2009). Combining chemical genomics screens in yeast to reveal spectrum of effects of chemical inhibition of sphingolipid biosynthesis. BMC microbiology 9:9.

158. Fabrizio P, Pozza F, Pletcher SD, Gendron CM, Longo VD (2001). Regulation of longevity and stress resistance by Sch 9 in yeast. Science 292(5515): 288-290.

159. Swinnen E, Ghillebert R, Wilms T, Winderickx J (2013). Molecular mechanisms linking the evolutionary conserved TORC1-Sch9 nutrient signalling branch to lifespan regulation in Saccharomyces cerevisiae. FEMS yeast research 14(1): 17-32.

160. Liu J, Huang X, Withers BR, Blalock E, Liu K, Dickson RC (2013). Reducing sphingolipid synthesis orchestrates global changes to extend yeast lifespan. Aging cell 12(5): 833-841.

161. Yoneda T, Benedetti C, Urano F, Clark SG, Harding HP, Ron D (2004). Compartment-specific perturbation of protein handling activates genes encoding mitochondrial chaperones. Journal of cell science 117(Pt 18): 4055-4066.

162. Kimura K, Tanaka N, Nakamura N, Takano S, Ohkuma S (2007). Knockdown of mitochondrial heat shock protein 70 promotes progeria-like phenotypes in Caenorhabditis elegans. The Journal of biological chemistry 282(8): 5910-5918.

163. Menzel R, Yeo HL, Rienau S, Li S, Steinberg CE, Sturzenbaum SR (2007). Cytochrome P450s and short-chain dehydrogenases mediate the toxicogenomic response of PCB52 in the nematode Caenorhabditis elegans. Journal of molecular biology 370(1): 1-13.

164. Liu Y, Samuel BS, Breen PC, Ruvkun G (2014). Caenorhabditis elegans pathways that surveil and defend mitochondria. Nature 508(7496): 406-410.

165. Zhang J (2013). Autophagy and Mitophagy in Cellular Damage Control. Redox biology 1(1): 19-23.

166. El Bawab S, Roddy P, Qian T, Bielawska A, Lemasters JJ, Hannun YA (2000). Molecular cloning and characterization of a human mitochondrial ceramidase. The Journal of biological chemistry 275(28): 21508-21513.

167. Bionda C, Portoukalian J, Schmitt D, Rodriguez-Lafrasse C, Ardail $D$ (2004). Subcellular compartmentalization of ceramide metabolism: MAM (mitochondria-associated membrane) and/or mitochondria? The Biochemical journal 382(Pt 2): 527-533.

168. Yabu T, Shimuzu A, Yamashita M (2009). A novel mitochondrial sphingomyelinase in zebrafish cells. The Journal of biological chemistry 284(30): 20349-20363.

169. Wu BX, Rajagopalan V, Roddy PL, Clarke CJ, Hannun YA (2010). Identification and characterization of murine mitochondria-associated neutral sphingomyelinase (MA-nSMase), the mammalian sphingomyelin phosphodiesterase 5 . The Journal of biological chemistry 285(23): 17993-18002.

170. Itoh K, Nakamura K, lijima M, Sesaki H (2013). Mitochondrial dynamics in neurodegeneration. Trends in cell biology 23(2): 64-71.
171. Parra V, Eisner V, Chiong M, Criollo A, Moraga F, Garcia A, Hartel $S$, Jaimovich E, Zorzano A, Hidalgo C, Lavandero S (2008). Changes in mitochondrial dynamics during ceramide-induced cardiomyocyte early apoptosis. Cardiovascular research 77(2): 387-397.

172. Loson OC, Song Z, Chen H, Chan DC (2013). Fis1, Mff, MiD49, and MiD51 mediate Drp1 recruitment in mitochondrial fission. Molecular biology of the cell 24(5): 659-667.

173. Ciarlo L, Manganelli V, Garofalo T, Matarrese P, Tinari A, Misasi R, Malorni W, Sorice M (2010). Association of fission proteins with mitochondrial raft-like domains. Cell death and differentiation 17(6): 1047-1058.

174. Smith ME, Tippetts TS, Brassfield ES, Tucker BJ, Ockey A, Swensen AC, Anthonymuthu TS, Washburn TD, Kane DA, Prince JT, Bikman BT (2013). Mitochondrial fission mediates ceramide-induced metabolic disruption in skeletal muscle. The Biochemical journal 456(3): 427 439.

175. Malathi K, Higaki K, Tinkelenberg AH, Balderes DA, AlmanzarParamio D, Wilcox L, Erdeniz N, Redican F, Padamsee M, Liu Y, Khan S, Alcantara F, Carstea ED, Morris JA, Sturley SL (2004). Mutagenesis of the putative sterol-sensing domain of yeast Niemann Pick C-related protein reveals a primordial role in subcellular sphingolipid distribution. The Journal of cell biology 164(4): 547-556.

176. Ferenci $P$ (2006). Regional distribution of mutations of the $A T P 7 B$ gene in patients with Wilson disease: impact on genetic testing. Human genetics 120(2): 151-159.

177. Swinnen E, Wilms T, Idkowiak-Baldys J, Smets B, De Snijder P, Accardo S, Ghillebert R, Thevissen K, Cammue B, De Vos D, Bielawski J, Hannun YA, Winderickx J (2014). The protein kinase Sch9 is a key regulator of sphingolipid metabolism in Saccharomyces cerevisiae. Molecular biology of the cell 25(1): 196-211.

178. Kitagaki $\mathrm{H}$, Cowart LA, Matmati N, Vaena de Avalos $\mathrm{S}$, Novgorodov SA, Zeidan YH, Bielawski J, Obeid LM, Hannun YA (2007). Isc1 regulates sphingolipid metabolism in yeast mitochondria. Biochimica et biophysica acta 1768(11): 2849-2861.

179. Okamoto Y, Vaena De Avalos S, Hannun YA (2002). Structural requirements for selective binding of $I s c 1 p$ to anionic phospholipids. The Journal of biological chemistry 277(48): 46470-46477.

180. Airola MV, Hannun YA (2013). Sphingolipid metabolism and neutral sphingomyelinases. Handbook of experimental pharmacology 215: $57-76$

181. Barbosa AD, Osorio $H$, Sims KJ, Almeida T, Alves M, Bielawski J, Amorim MA, Moradas-Ferreira P, Hannun YA, Costa V (2011). Role for Sit4p-dependent mitochondrial dysfunction in mediating the shortened chronological lifespan and oxidative stress sensitivity of Isc1p-deficient cells. Molecular microbiology 81(2): 515-527.

182. Kitagaki H, Cowart LA, Matmati N, Montefusco D, Gandy J, de Avalos SV, Novgorodov SA, Zheng J, Obeid LM, Hannun YA (2009). Isc1-dependent metabolic adaptation reveals an indispensable role for mitochondria in induction of nuclear genes during the diauxic shift in Saccharomyces cerevisiae. The Journal of biological chemistry 284(16): 10818-10830.

183. Stark MJ (1996). Yeast protein serine/threonine phosphatases: multiple roles and diverse regulation. Yeast 12(16): 1647-1675.

184. Hohmann S, Krantz M, Nordlander B (2007). Yeast osmoregulation. Methods in enzymology 428:29-45.

185. Bilsland E, Molin C, Swaminathan S, Ramne A, Sunnerhagen P (2004). Rck1 and Rck2 MAPK kinases and the HOG pathway are required for oxidative stress resistance. Molecular microbiology 53(6): 1743-1756. 
186. Rep M, Proft M, Remize F, Tamas M, Serrano R, Thevelein JM, Hohmann S (2001). The Saccharomyces cerevisiae Sko1p transcription factor mediates HOG pathway-dependent osmotic regulation of a set of genes encoding enzymes implicated in protection from oxidative damage. Molecular microbiology 40(5): 1067-1083.

187. Saito H, Posas F (2012). Response to hyperosmotic stress. Genetics 192(2): 289-318.

188. Vanier MT, Millat G (2003). Niemann-Pick disease type C. Clinical genetics 64(4): 269-281.

189. Karten B, Peake KB, Vance JE (2009). Mechanisms and consequences of impaired lipid trafficking in Niemann-Pick type C1deficient mammalian cells. Biochimica et biophysica acta 1791(7): 659-670.

190. Loftus SK, Morris JA, Carstea ED, Gu JZ, Cummings C, Brown A, Ellison J, Ohno K, Rosenfeld MA, Tagle DA, Pentchev PG, Pavan WJ (1997). Murine model of Niemann-Pick $C$ disease: mutation in a cholesterol homeostasis gene. Science 277(5323): 232-235.

191. Carstea ED, Morris JA, Coleman KG, Loftus SK, Zhang D, Cummings C, Gu J, Rosenfeld MA, Pavan WJ, Krizman DB, Nagle J, Polymeropoulos $\mathrm{MH}$, Sturley SL, Ioannou YA, Higgins ME, Comly M, Cooney A, Brown A, Kaneski CR, Blanchette-Mackie EJ, Dwyer NK, Neufeld EB, Chang TY, Liscum L, Strauss JF, 3rd, Ohno K, Zeigler M, Carmi R, Sokol J, Markie D, et al. (1997). Niemann-Pick C1 disease gene: homology to mediators of cholesterol homeostasis. Science 277(5323): 228-231.

192. Naureckiene $S$, Sleat $D E$, Lackland $H$, Fensom A, Vanier MT, Wattiaux $\mathrm{R}$, Jadot $\mathrm{M}$, Lobel $\mathrm{P}$ (2000). Identification of $H E 1$ as the second gene of Niemann-Pick C disease. Science 290(5500): 22982301.

193. McLean KJ, Hans M, Munro AW (2012). Cholesterol, an essential molecule: diverse roles involving cytochrome P450 enzymes. Biochemical Society transactions 40(3): 587-593.

194. Bi X, Liao G (2010). Cholesterol in Niemann-Pick Type C disease. Sub-cellular biochemistry 51:319-335.

195. Boomkamp SD, Butters TD (2008). Glycosphingolipid disorders of the brain. Sub-cellular biochemistry 49:441-467.

196. Vazquez MC, Balboa E, Alvarez AR, Zanlungo S (2012). Oxidative stress: a pathogenic mechanism for Niemann-Pick type C disease. Oxidative medicine and cellular longevity 2012:205713.

197. Kennedy BE, LeBlanc VG, Mailman TM, Fice D, Burton I, Karakach TK, Karten B (2013). Pre-symptomatic activation of antioxidant responses and alterations in glucose and pyruvate metabolism in Niemann-Pick Type C1-deficient murine brain. PloS one 8(12): e82685.

198. Klein A, Maldonado C, Vargas LM, Gonzalez M, Robledo F, Perez de Arce K, Munoz FJ, Hetz C, Alvarez AR, Zanlungo S (2011). Oxidative stress activates the c-Abl/p73 proapoptotic pathway in Niemann-Pick type $C$ neurons. Neurobiology of disease 41(1): 209-218.

199. Fu R, Yanjanin NM, Bianconi S, Pavan WJ, Porter FD (2010). Oxidative stress in Niemann-Pick disease, type C. Molecular genetics and metabolism 101(2-3): 214-218.

200. Yu W, Gong JS, Ko M, Garver WS, Yanagisawa K, Michikawa M (2005). Altered cholesterol metabolism in Niemann-Pick type C1 mouse brains affects mitochondrial function. The Journal of biological chemistry 280(12): 11731-11739.

201. Zervas M, Somers KL, Thrall MA, Walkley SU (2001). Critical role for glycosphingolipids in Niemann-Pick disease type C. Current biology : CB 11(16): 1283-1287.

202. Higaki K, Almanzar-Paramio D, Sturley SL (2004). Metazoan and microbial models of Niemann-Pick Type $C$ disease. Biochimica et biophysica acta 1685(1-3): 38-47.
203. Zhang S, Ren J, Li H, Zhang Q, Armstrong JS, Munn AL, Yang H (2004). Ncr1p, the yeast ortholog of mammalian Niemann Pick C1 protein, is dispensable for endocytic transport. Traffic 5(12): 10171030

204. Lees ND, Bard M, Kirsch DR (1999). Biochemistry and molecular biology of sterol synthesis in Saccharomyces cerevisiae. Critical reviews in biochemistry and molecular biology 34(1): 33-47.

205. Vilaca R, Silva E, Nadais A, Teixeira V, Matmati N, Gaifem J, Hannun YA, Sa Miranda MC, Costa V (2014). Sphingolipid signalling mediates mitochondrial dysfunctions and reduced chronological lifespan in the yeast model of Niemann-Pick type C1. Molecular microbiology 91(3): 438-451.

206. Brett CL, Kallay L, Hua Z, Green R, Chyou A, Zhang Y, Graham TR, Donowitz M, Rao R (2011). Genome-wide analysis reveals the vacuolar $\mathrm{pH}$-stat of Saccharomyces cerevisiae. PloS one 6(3): e17619.

207. Schneiter R (2007). Intracellular sterol transport in eukaryotes, a connection to mitochondrial function? Biochimie 89(2): 255-259.

208. Berger AC, Hanson PK, Wylie Nichols J, Corbett AH (2005). A yeast model system for functional analysis of the Niemann-Pick type $C$ protein 1 homolog, Ncr1p. Traffic 6(10): 907-917.

209. Munkacsi AB, Chen FW, Brinkman MA, Higaki K, Gutierrez GD, Chaudhari J, Layer JV, Tong A, Bard M, Boone C, loannou YA, Sturley SL (2011). An "exacerbate-reverse" strategy in yeast identifies histone deacetylase inhibition as a correction for cholesterol and sphingolipid transport defects in human Niemann-Pick type $C$ disease. The Journal of biological chemistry 286(27): 23842-23851.

210. Lorenz RT, Rodriguez RJ, Lewis TA, Parks LW (1986). Characteristics of sterol uptake in Saccharomyces cerevisiae. Journal of bacteriology 167(3): 981-985.

211. Lopez-Rodas G, Brosch G, Georgieva El, Sendra R, Franco L, Loidl $P$ (1993). Histone deacetylase. A key enzyme for the binding of regulatory proteins to chromatin. FEBS letters 317(3): 175-180.

212. El-Osta A, Wolffe AP (2000). DNA methylation and histone deacetylation in the control of gene expression: basic biochemistry to human development and disease. Gene expression 9(1-2): 63-75.

213. Neubauer HA, Pitson SM (2013). Roles, regulation and inhibitors of sphingosine kinase 2. The FEBS journal 280(21): 5317-5336.

214. Glozak MA, Seto E (2007). Histone deacetylases and cancer. Oncogene 26(37): 5420-5432.

215. Hait NC, Allegood J, Maceyka M, Strub GM, Harikumar KB, Singh SK, Luo C, Marmorstein R, Kordula T, Milstien S, Spiegel S (2009). Regulation of histone acetylation in the nucleus by sphingosine-1phosphate. Science 325(5945): 1254-1257.

216. Maceyka M, Milstien S, Spiegel S (2013). The potential of histone deacetylase inhibitors in Niemann - Pick type C disease. The FEBS journal 280(24): 6367-6372.

217. Loudianos G, Gitlin JD (2000). Wilson's disease. Seminars in liver disease 20(3): 353-364.

218. Huster D (2010). Wilson disease. Best practice \& research Clinical gastroenterology 24(5): 531-539.

219. Bull PC, Thomas GR, Rommens JM, Forbes JR, Cox DW (1993) The Wilson disease gene is a putative copper transporting P-type ATPase similar to the Menkes gene. Nature genetics 5(4): 327-337.

220. Ala A, Walker AP, Ashkan K, Dooley JS, Schilsky ML (2007). Wilson's disease. Lancet 369(9559): 397-408. 
221. Fu D, Beeler TJ, Dunn TM (1995). Sequence, mapping and disruption of $C C C 2$, a gene that cross-complements the $\mathrm{Ca}\left({ }^{2+}\right)$-sensitive phenotype of csg1 mutants and encodes a P-type ATPase belonging to the $\mathrm{Cu}\left({ }^{2+}\right)$-ATPase subfamily. Yeast 11(3): 283-292.

222. Dancis A, Haile D, Yuan DS, Klausner RD (1994). The Saccharomyces cerevisiae copper transport protein (Ctr1p). Biochemical characterization, regulation by copper, and physiologic role in copper uptake. The Journal of biological chemistry 269(41): 25660-25667.

223. Lin SJ, Pufahl RA, Dancis A, O'Halloran TV, Culotta VC (1997). A role for the Saccharomyces cerevisiae ATX1 gene in copper trafficking and iron transport. The Journal of biological chemistry 272(14): 92159220 .

224. Yuan DS, Stearman R, Dancis A, Dunn T, Beeler T, Klausner RD (1995). The Menkes/Wilson disease gene homologue in yeast provides copper to a ceruloplasmin-like oxidase required for iron uptake. Proceedings of the National Academy of Sciences of the United States of America 92(7): 2632-2636.

225. Cankorur-Cetinkaya A, Eraslan S, Kirdar B (2013). Transcriptional remodelling in response to changing copper levels in the Wilson and Menkes disease model of Saccharomyces cerevisiae. Molecular bioSystems 9(11): 2889-2908.

226. lida M, Terada K, Sambongi Y, Wakabayashi T, Miura N, Koyama K, Futai M, Sugiyama T (1998). Analysis of functional domains of Wilson disease protein (ATP7B) in Saccharomyces cerevisiae. FEBS letters 428(3): 281-285.
227. Forbes JR, Cox DW (1998). Functional characterization of missense mutations in $A T P 7 B$ : Wilson disease mutation or normal variant? American journal of human genetics 63(6): 1663-1674.

228. Mullen TD, Obeid LM (2012). Ceramide and apoptosis: exploring the enigmatic connections between sphingolipid metabolism and programmed cell death. Anti-cancer agents in medicinal chemistry 12(4): 340-363.

229. De Coninck B, Carron D, Tavormina P, Willem L, Craik DJ, Vos C, Thevissen K, Mathys J, Cammue BP (2013). Mining the genome of Arabidopsis thaliana as a basis for the identification of novel bioactive peptides involved in oxidative stress tolerance. Journal of experimental botany 64(17): 5297-5307.

230. Spincemaille $P$, Chandhok G, Newcomb B, Verbeek J, Vriens K, Zibert A, Schmidt H, Hannun YA, van Pelt J, Cassiman D, Cammue BP, Thevissen K (2014). The plant decapeptide OSIP108 prevents copperinduced apoptosis in yeast and human cells. Biochimica et biophysica acta 1843(6): 1207-1215.

231. Park JW, Park WJ, Futerman AH (2014). Ceramide synthases as potential targets for therapeutic intervention in human diseases. Biochimica et biophysica acta 1841(5): 671-681. 